\title{
THE EFFECT OF ENGLISH AND CANTONESE SPEAKING ABILITY OF THE INDONESIAN FEMALE MIGRANT WORKERS IN HONGKONG TOWARD PEOPLE AROUND THEM
}

(3 May - 8 May 2017)

\section{B. Rachmawati}

\begin{abstract}
The globalization era, requires some life aspects to be mastered. One of the aspects is the ability to communicate among others in any languages as communication tool to interact with the world community. The fact that Indonesia migration of labors had a big number of portion since the Dutch East Indies Government, makes the mastery of foreign language important. Most of the migrant workers of Indonesia are women. They migrate abroad because of economic difficulties. For that, they are willing to become domestic helper to improve the economic conditions of their families. Having enough and compatibel skills are very important to minimize the problems that arise with the fellow and people around them. The training for these migrant workers are conducted by Indonesian Manpower Supplier (PJTKI) where they can get such Training CenterForeign Affairs (BLK -LN). By doing the training, the migrant workers will get some skills like basic skill and interpersonal skills. Female migrant workers get English and cantonese language, especially for those who work in Hongkong. The training is done in 4 months including daily foreign language speaking practice. The objective of the training are to help the female migrant workers in bargaining position and more appreciate existence.
\end{abstract}

Keywords: Ability to speak English, Cantonese, communication

\section{A. INTRODUCTION}

\section{Background}

In the era of globalization, here are some life aspects to be completed. It puts foreign language mastery in strategic position. By mastering foreign languages, in this case English and Cantonese, makes it become an instrument to interact in the society.

The strategy to communicate in foreign language become an instrument to interact with community. In this globalization era is the International migrant of Indonesian worker. The form of migrant by Indonesia is the sending of labor to abroad. The delivery of labor to abroad has been started since the Dutch east 
Indies. It was still governed by the Dutch east Indies government through Werving oronantie 1938 no 388 on the rules of execution of Indonesian mobilization to carry out its work in overseas.

Indonesian worker (TKI) are people who have difficulty living to work overseas in certain period. Delivery of migrant workers mostly are women. They are willing to be domestic helper to pit their fate because of poverty who drives them to work in overseas. They need on economic improvement for welfare of their family. Self preparation for the migrant workers before they left is an important thing and main addition to administrative completeness. Through Indonesian labor supplier (PJTKI) . PJTKI is a place which provides training to prospective worker who tries working overseas. The training objective are to provide female migrant worker (TKW) bargaining position and their existence is more appreciated as professional work force.

Female migrant workers training center (BLK) is required to be able to work fast, skilled and disciplined. Learning method in language skill training which emphasizes on aspect improving speaking skill both oral and written.

This language learning activity is held for 4 months (depends on visa) however, if they are not motivated to practice speaking in accordance in ability to communicate in foreign language (English and Cantonese) it can cuse migrant female workers' problem with employer and people around them abroad.

By the ability to communicate in foreign language, especially in this case English and Cantonese will facilitate them to communicate with people around them.

Based on the description above, the writer intends to do research on the effect of English and Cantonese speaking ability of the Indonesian female workers in Hongkong toward people around them.

\section{Objectives}

The objectives of this research are (1) to find out how far the speaking ability of English and Cantonese of female migrant workers (TKW) effects to the fellow; (2) to know how far the speaking ability of English and Cantonese of female migrant workers (TKW) effects to the colleague; and (3) to understand how far the 
speaking ability of English and Cantonese of female migrant workers (TKW) effects to other people.

\section{Methodology}

In this research, the writer used cross sectional survey which the information data is collected only on certain moments. The subjects of research were female migrant workers who live in Hong Kong. Five workers are taken as sample. By using convenience sampling, that is a sample by a chance who anyone incidentally met, the writer can use as sample and suitable as data source.

\section{B. RESULT AND DISCUSSION}

The result of research conducted in Hongkong with female migrant workers (TKW) as respondednt on 3-8 May 2017

1. Respondent named Eva ( 29 years old - Cirebon)

1) Fellow behavior

Eva works as dosmetic helper and takes care elderly in Macao. Her fellow is good young man. They use Cantonese to communicate. If her work is not pleased her fellow reminds firmly. But if her works are satisfying, her fellow gives a thumb up ( good job cues)

2) Colleague

Eva has a close friend from Philiphine, Vietnam, and China

They speak english an Cantonese for daily communication. When Eva goes outside, she usually speaks Cantonese. According Eva, Cantonese should be learnt for every workers who work in Hongkong.

3) Training center ( BLK)

Before Eva works in Macao, eva join training at training center (BLK) It has many programs. The most favorite program for her is cooking.

2. Respondent named Ana Lewakabeshi ( 26 years old - Nusa Tenggara Timur) 1). Fellow behavior

Ana works as domestic helper in Sham Sui Poo. The fellow is very good. They speak English for daily communication. If her work is not pleased 
her fellow will say "em cung" it means do not to do this. but if her works are satisfying she will say "leek" it means "smart " while holding up the tumb.

2) Colleague

Ana has many friends from Indian, Vietnames, and Philipino. They communicate in English. When she has spare times. She learns Cantonese in an institution in Kowloon

3) Training center ( BLK)

In the training hall, there are many skill subjects were taught. But the most she likes is caring for elderly. This training has positive impact for her work.

3. Respondent named Istiqomah ( 43 years old - klaten)

1) Fellow behavior

She works as domestic helper in Tung Cung. Her employer use Cantonese for daily communication. Her fellow is good. if her work is not pleased, her fellow just reminds her. But if her work satisfying, her feloow praises her.

2) Colleague

Isti has many friends from Indonesia and work as migrant female workers in Hongkong. She also has many friends from Pakistan, Yaman. She speaks English for communication.

3) Training center ( BLK)

There are many programs available in training center. But cooking is the most program that she likes. By this training gets some positive impacts.

4. Respondent named Dewi Riyatun ( 25 years old - cilacap)

1) Fellow behavior

Dewi works as domestic helper in Laiking. The main job are keeping the elderly and keeping the house. She usually speaks English and Cantonese . Her fellow is quite good. If her work is not pleased her fellow just reminds her. But if her work satisfying her fellow praises her.

2) Colleague 
Dewi has many friends from Philiphine, she speaks English for their communication

3) Training center ( BLK)

Training center has many programs but the most she likes is taking care elderly because it is very useful for helping other people.

5. Respondent named Mugi Asih ( 37 years old - Wonosobo)

1) Fellow behavior

Asih works as domestic helper in Peng Chau Wing Hings St. her fellow is very good. They speak English for daily communication. If her work is not pleased her fellow just reminds her. But if her work is satisfying her fellow say "good job. "

2) Colleague

Most of her friends are from Indonesia. They communicate in Bahasa.

3) Training center ( BLK)

There are many programs in training centre and she can master them well.

Two positive things are deft and discipline. So she can apply them in her work.

Through interviews which the writer did with female migrant workers ( TKW) who work as domestic helper, mostly they work from Monday to Friday. Saturday and Sunday are their day off. During the holiday, they gather in Kowloon park. Or in Islamic Kowloons mosque. As for usual activities they do "arisan", reciting qur'an and many more.

There are also Cantonese learning activity organized in 2008. It was conducted by Hongkong institution. Which all teacher staffs are hongkongnese. It was held by $\mathrm{KJRI}$ in cooperated with young scholar education and Indonesia diaspora also entrepreunerial learning activities through selling Indonesia cuisine which is placed on a box of food.

The research used cross sectional survey appears the female workers show have been living there for years. Fluent in English and Cantonese to communicate with people around them based on the writer has been done while in Hongkong for 6 days. 
1) The Effect of English and Cantonese speaking ability of female migrant workers toward the fellow.

Most of female workers speaking Cantonese in daily communication but there are also fellows who speak English with the reasons that English is more important to be communicated in the world. In order to understand English and Cantonese they must understand what means of speakers ( fellow) in order to avoid misinterpretation. By good communication, the female migrant workers will be easy doing their job, so the fellows will be kind to be female migrant workers.

2) The Effect of English and Cantonese speaking ability of female migrant workers toward the celleague.

The female migrant workers speak bahasa when they communicate with Indonesian. But when they met with people from antoher country they speak English and sometimes they speak Cantonese as local language.

3) he Effect of English and Cantonese speaking ability of female migrant workers toward the other people.

The female migrant workers (TKW) in Hongkong interact with many people, for example when they go shopping. Ask information to the officer. They speak English or Cantonese. This training Center (BLK) is needed to support the placement of overseas female migrant female workers. The trainings includes basic skills, interpersonal skills and self-atributes training. These skills incude culinary, house keeping, dressing / laundry, baby care and languages.

In training center ( BLK) foreign language are taught pronounciation of articulation sounds to express their idea or feelings. The technique uses the form of imitate teacher utter sounds. The teacher corrects the articulation then students will imitate what the teacher utter ( drill pattern)

\section{CONCLUSION}

Based on the result of research shows that

a. Speaking ability is a skill to deliver ideas among others. 
b. Speaking ability is a tool to conduct the activity to develop good communication that is needed to help in understanding each other for common interest

c. Through good communication of female migrant workers it will be easy for them in doing their job and their fellow will be kind to the female migrant workers .

\section{BIBLIOGRAPHY}

Apriawan. Keterampilan berbicara. Di akses Januari 23, 2009 dari http//apriawan. Blogspot.com/2007/03kemampuan linguistic.html.online

Chomsky. (1965) Aspect of Theory Syntax. Massachussetts: Massachussetts Institute of Technology Cambridge: Cambridge University Press

Clark, Herbert \&Clark, Eve (1997). Psychology and Language. New York: Harcout Brace Jovonocie, Inc.

ejournal.

$$
\text { Pengaruh Komunikasi }
$$

Organisasi

dari

https://ejournal.unsrat.ac.id/index.php/actadurnal/article/ viewFile/16371308

Hamalik Oemar (2014). Psikologi Belajar dan Mengajar. Bandung: Sinar Baru Algesindo.

Keraf, Gorys (1991). Diksi dan Gaya Bahasa. Jakarta: Gramedia.

Rikinugroho. Komunikasi Dalam Kelompok. Dari http//rikinugroho. blogspot.com/2011/10/unsur-unsur-komunikasi-dalam-organisasi.html

Pengertian Komunikasi. Digilib.unila.ac.id/1613/5/LANDASAN\%20TEORI.pdf Sahertian, A Piet dan Sahertian Ida (1991). Supervisi Dalam Pendidikan Dalam Rangka Program

Intervice Education. Jakarta : Gramedia. 
Setiadi, M, Elly, Hakim Abdul Kamal (2008). Ilmu Sosial dan Budaya Dasar. Jakarta: Kencana.

Sugiyono, (2006). Metode Penelitian Administrasi. Bandung: Anggota Ikatan Penerbit Indonesia ( IKAPI.)

Tarigan, Henry Guntur (1951). Berbicara sebagai suatu keterampilan berbahasa. Bandung : Angkasa

Widowson (1973). Teaching as Communication. United Kingdom: Oxford University Press. 